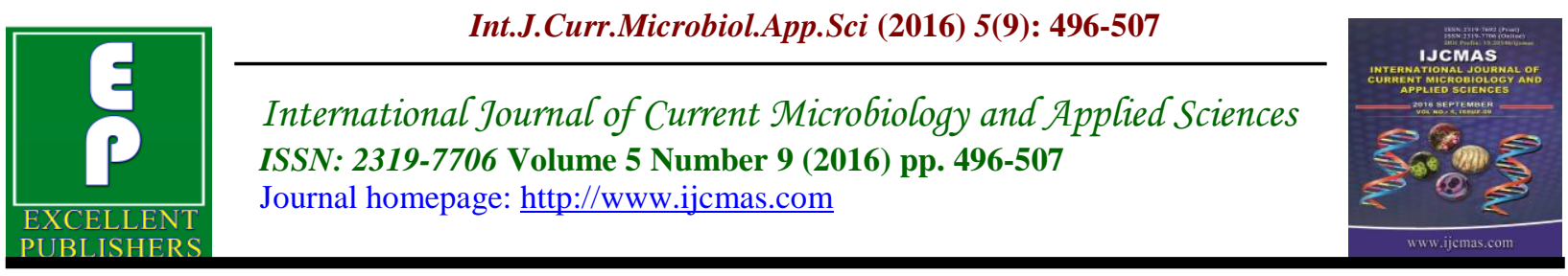

Original Research Article

http://dx.doi.org/10.20546/ijcmas.2016.509.055

\title{
Prevalence of Gyrodactylus sp. in Channa punctatus (Bloch, 1793) Monogenean Ecto-parasite Family: Gyrodactylidae at Lower Manair Dam
}

\author{
Leela Bommakanti* \\ Government Degree and PG College, Jammikunta, Karimnagar Dt. Telangana State, India \\ *Corresponding author
}

Keywords

Monogenean, Gyrodactylus sp, Haptors,

Prevalence, relative density, Index of infection.

Article Info

Accepted:

20 August 2016

Available Online:

10 September 2016
A B S T R A C T

Monogenean trematodes are parasitic Gyrodactylus sp. flatworms that are found on gills of Channa punctatus. The body elongated, dorso- ventrally flattened; body measures $410.5 \mu(324-630 \mu)$ in length and width at the pharyngeal level, $94.5 \mu$ (90-108 $\mu$ ), at middle region, $98 \mu(90-108 \mu)$ and at the posterior end, $79 \mu(54-90$ $\mu)$. Anterior part of the body bi-lobed, provided with a pair of antero-lateral papillae and head organs in either lobe. Pharynx is oval $33 \mu$ (31.5 -43 $\mu$ ) long, 37 $\mu(34-45 \mu)$ wide. It consists of two lobes. The anterior prepharynx $17 \mu(11-22 \mu)$ long, $26 \mu(25-27 \mu)$ wide, while the posterior pharynx proper $13.5 \mu(11-16 \mu)$ long, $36 \mu(31.5-40.5 \mu)$ wide. Haptor slightly demarcated from the body, sub circular, $68.5(58.5-94.5 \mu)$ long, $66.5(54-90 \mu)$ wide with fringed margin, each projection accommodating a hooklet. The prevalence of monogenean parasites in Channa punctatus were recorded during the study period from August 2015 to July 2016. As per Margolis the prevalence of the parasites is $45.04 \%$ and mean intensity level of $01.95 \%$, relative density is $0.88 \%$ and index of infection is $2.5 \%$ to $15.12 \%$ represents rare and occasional in the Lower Manair Dam.

\section{Introduction}

Monogenean trematodes are a parasitic flatworms that are commonly found on fishes and lower aquatic invertebrates. Monogeneans are browsers that move about freely on the fish's body surface feeding on mucus and epithelial cells of the skin and gills; however, a few adult monogeneans will remain permanently attached to a single site on the host. The monogenean species invade the rectal cavity, ureter, body cavity, and even the blood vascular system. Monogenean trematodes are between 4,000 and 5,000 species of monogeneans had been described. They are found on fishes in fresh and salt water and in a wide range of water temperature. Monogeneans are a class of parasitic flatworms that are commonly found on fishes and lower aquatic invertebrates. Most of monogeneans were browsers that move about freely on the fish's body surface feeding on mucus and epithelial cells of the skin and gills; however a few adult monogeneans will remain permanently attached to a single site on the host. Some monogenean species invade the rectal cavity, ureter, body cavity, and even 
the blood vascular system. Between 4,000 and 5,000 species of monogeneans had been described. They are found on fishes in fresh and marine waters and in a wide range of water temperatures. Captive fishes are usually held in more crowded conditions than fishes in the natural environment. This practice allows hatching monogeneans to easily find host fish. In addition to that stressors found in the captive environment such as aggressive behaviour by tank mates, poor nutrition, and poor water quality may impact the ability of the fish's immune system to respond to the presence of the parasites. Although monogeneans are commonly found on wild fish, they seldom cause disease or death in free-ranging populations because under natural conditions they are usually not present in high numbers on individual fish.

Monogeneans are found on fresh and saltwater fishes throughout the world. They have a direct life cycle and can reproduce in a wide range of temperatures. The hook-like structures of monogeneans are used to attach to the fish body. Monogenean infestations cause irritation and excessive mucus production and create an opening for bacterial invasion. A few monogeneans on a healthy mature fish are not usually significant; however, moderate numbers can cause significant mortalities. When fish are exposed to environmental or behavioral stressors, the potential damage from monogeneans is greater. Prevention of monogenean infestations by appropriate quarantine is preferable to treatment of the parasites after they have become established in a system. A comparative account of the measurements of different parts of the nine described species of Gyrodactylus from India, including the present one has been presented and considered the chitinoid armament as the key feature of the species demarcation, then the newly described one shows its close proximity with $G$. recurvensis. Because the anchor measurements have close resemblance but the main part differs. Again a measurement of marginal hook shows similarity but differs highly in deep bar and superficial bar. Although these two species show similarities, close observation reveals $G$. recllrvensis is smaller in dimension in all aspects of 'hard parts' with the newly described one. If we consider the other measurements like body length, width, pharynx, haptor etc., there is marked difference between the two species. Actually, G. recllrvensis is almost half or less in length than the presently described species. Another species G. mizellei shows close resemblance with the presently described one In anchor, superficial bar and marginal hook measurements. But the deep bar differs greatly. 'Hard parts' of G. Inizellei are larger in dimension when all the measurements are compared. Comparison shows $G$. nlizellei is almost three times larger in length than the presently described species. The hooklet length and shaft shows resemblance with $G$. eutheraponsis, but the other parts differs significantly. Even $G$. eutheraponsis can be well demarked in the species level as it described different habitat. As regard to the anchor measurements of $G$. hyderabadensis with the described one, the main part, base and point shows resemblance, but the measurement of marginal hook is quite different and even the other measurements viz. the length of the body, width, pharynx show variations.

The majority of gyrodactylids were viviparous and are generally found on the bodies and fins of fish, though they occasionally may occur on the gills. Adult parasites carry fully developed embryos, which in turn carry the young of the next generation. Each individual parasite represents several generations, which is why 
they are often referred to as Russian nesting dolls. This reproductive strategy allows populations of gyrodactylids to multiply very quickly, especially in a closed system. The few gyrodactylids that are egg-layers are usually found on members of the South American catfish families, Loricariidae and Pimelodidae. These gyrodactylids use an adhesive material to "glue" their eggs to the skin of the catfish. Gyrodactylids may be found on freshwater, marine, and brackish water fishes. Gyrodactylids have a pair of anchors with both dorsal and ventral bars and 16 marginal hooks, and do not have eye spots. Attachment to the fish is made with the marginal hooks; the anchors are used as a spring-like device to assist attachment with the marginal hooks. An embryo with its pair of anchors may frequently be seen inside an adult. For a considerable proportion of existing biodiversity, these questions are increasingly being asked in relation to parasitic organisms represented by Brooks et al., (2000). Monogeneans are the most ubiquitous and abundant group of helminth parasites in the aquatic environment is indicated by Ivona (2004) and Bychowsky (1957). Among the monogenea, Dactylogyrus sp. was mostly observed in gills as compared to Gyrodactylus sp. which corroborate the earlier view discussed by Koskivaara and Valtonen (1992). Tripathi (1957) illustrated the monogenetic trematodes to Indian fishes.

\section{Material and Methods}

The common snake-headed fish Channa punctatus (Bloch, 1793) were collected from Lower Manair Dam, Karimnagar, Telangana State and were brought alive to the Govt. Degree and PG College, Zoology laboratory.

They were kept in the aquarium with aerated water; meanwhile, some fishes were observed to be a little discoloured and also found to move restlessly. They were taken out of the water and observed under binocular microscope. The parasites were teased out from the surface of the infected regions of the fishes and the parasites fixed directly in AFA for 3-5 minutes in the watch glass.

They were stained with semichons' Carnine. Some photomicrographs were taken by Zeiss Axiolab Microscope using MC-80 camera. Measurements were taken with the help of an ocular micrometer.

Distinguishing characteristics include the presence or absence of eye spots, and the number of pairs of anchors (hamuli), transverse bars, and marginal hooks on their haptors these features can only be seen with a compound microscope. The most common groups of monogeneans on freshwater fishes are the gyrodactylids and the ancyrocephalids, which differ markedly in their reproductive strategies as well as their preferred attachment sites on host fish.

\section{Identification}

Hooks and anchors on haptor., One pair of anchors with dorsal and ventral transverse bars; ventral bar has shield, Marginal Hooks 16, Eye spot absent, Marginal hooks: small hooks on the margin of the haptor; often used to attach to host

Hamuli: hook-like structures used by some monogeneans to attach to the host; also called anchors.

Parasite identification: Drawings of the parasites were made with the help of camera lucid. External and internal morphology of the parasites were sketched. Anterior and posterior regions of the parasite were drawn at high magnification in the laboratory. 


\section{Statistical Analysis}

Ecological terms are studied as per Margolis.

\section{(A) Prevalence $=$}

Total No. of Hosts Infected X 100

Total No. of Hosts Examined

(B) Mean Intensity =

Total No. of parasite

Total No. of Infected Hosts Examined

(C) Relative Density =

Total No. Parasites Or Abundance

Total No. of Hosts Examined

(d) Index of Infection =

No. of Hosts Infected $\times$ No. of parasites collected

Total No. of Hosts Examined

The Parasitic Frequency Index (PFI) was calculated by taking the percentage of the number of hosts infected by an individual parasite species against the total number of hosts examined in a particular area under investigation. Srivastava C.B. (1980) noted the frequency index were further classified into rare $(0.1-9.9 \%)$, occasional (10$29.9 \%)$, common $(30-69.9 \%)$ and abundant (70-100\%).

\section{Results and Discussion}

In the present study is Gyrodactylus sp. (Figure: 1). (All measurements in microns, range in parentheses; $N=20$ ). Body elongated, dorso- ventrally flattened; body measures $410.5 \mu(324-630 \mu)$ in length and width at the pharyngeal level, $94.5 \mu(90-$ $108 \mu)$, at middle region, $98 \mu(90-108 \mu)$ and at the posterior end, $79 \mu(54-90 \mu)$. Anterior part of the body bi-lobed, provided with a pair of antero-lateral papillae and head organs in either lobe. Globular vesicle present in the head organs, each terminates in an extrusible anterior spine. Pharynx is oval $33 \mu(31.5-43 \mu)$ long, $37 \mu(34-45 \mu)$ wide. It consists of two lobes. The anterior prepharynx $17 \mu(11-22 \mu)$ long, $26 \mu$ (25-27 $\mu$ ) wide, while the posterior pharynx proper $13.5 \mu(11-16 \mu)$ long, $36 \mu(31.5-40.5 \mu)$ wide. Haptor slightly demarcated from the body, sub circular, 68.5 (58.5-94.5 $\mu$ ) long, $66.5(54-90 \mu)$ wide with fringed margin, each projection accommodating a hooklet. According to Aniruddha Jha et al (2002) Gyrodactylus presidencyus sp. nov. (Trematoda: Monogenea) in West Bengal, an enlarged view of the haptor is Single marginal proper hooklets. Anchor is moderately stout and comprises three main parts, viz. root, shaft and point. Superficial anchor roots long, diverging; anchor points recurved; deep groove present in the anchor; anchor sharply pointed and curved. Anchor length $62 \mu(58.5-63 \mu)$; length of the main part (shaft length) $59.5 \mu(56-61 \mu)$, superficial root $21 \mu(22-22.5 \mu)$ long, base $9.5 \mu(9-11 \mu)$ wide, point $21 \mu(18-24 \mu)$. Deep bar (dorsal bar) slightly curved, situated above the ventral bar and well secured in between the anchor knobs, measuring $21 \mu(20-22.5 \mu)$ long and invariably $6.75 \mu$ wide. Superficial bar (ventral bar) is larger than the dorsal bar, it comprises three parts, a median portion, a posterior membranous process and has antero-lateral processes at the extremities. The measurements of the Gyrodactylus $s p$ have been similar to the present study of gill ectoparasites. Marginal hooks composed of a sickle proper, sickle membrane, a long 
handle, without sickle filament loop. Handle attached at the proximal part of the sickle. Articulating portion of handle is slender, straight attached at the outer most portion of the sickle, while the other end is slightly swollen for providing site for the attachment of muscles. Detailed measurements are as follows; total length 24 (22.5-27), sickle length 5 (4.5-6) and length of handle 15 (i718). Ovary triangular, pretesticular, 38 (3645) long, 30.5 (27-36) wide. Uterus enclosing a fully developed embryo with its anchors observed in few flukes. Test is post ovarian, elongated and measures 16.5 (1618) long, 22 (20- 22.5) wide. Anteriorly it gives rise to a vas deferens runs forward and finally joins at the base of cirrus pouch. The spherical cirrus situated below the pharynx 16.5 (16-18) long and 14 (13.5-16) wide. Type Host: Channa punctatus (Bloch) Site of Infection: Skin, Gills Especially on the surface towards caudal peduncle, bases of the fin rays, caudal, and anal, in gills and in branchiostegal area. Bakke et al., (2002), Bychowsky (1962) and Venkatanarsaiah and Kulkarni, 1980 noted the host specificity dynamics and observations of gills on gyrodactylid.

Gussev (1978) studied that the peculiarities of chitinoid armament of attachment disk, viz. number, shape, dimension and functioning of anchors, connecting bars and hooks are of great significance in species and generic diagnosis. Malmberg (1970) had earlier suggested that dimensions and shape of hooks represent the most constant characteristics of species of gyrodactylids of all the armament features. Anchors and connecting bars thus become very important in the species demarcation in gyrodactylids. Concise keys and supplementary diagnostic features for most species of Gyrodactylids from Eurasia and North America are available from the works of Gussev (1985) and Beverly-Burton (1984). Gyrodactylus anguillae has been found to parasitise on eels, Anguilla rostrata and A. anguilla indicated by Malmberg (1970) and is considered as euryhaline species. Cone et al., (1983) studied both Gyrodactylus salnsis and $G$. colenlanensis are common parasites of salmonid fishes in North America.

Another species, Gyrodactylus crysoleucas parasitises golden shiner (Notemigonus crysoleucas) and causes significant disease in bait fishes in the southern United States represented by Lewis and Lewis (1970). Gyrodactylus ictaluri has been described from channel catfishes (Ictalurus punctatus) of south eastern United States by Hoffman (1979) and $G$. katharineri parasitises Cyprinus carpio throughout Eurasia and caused disease problems in carp ponds. Gyrodactylus turnbulli, a common parasite has been reported from imported Poecilia reticulata of Singapore to England (Harris, 1986). A comparison of diagnostic specific characters of the above parasites with the present described one shows not only differences of measurements but also differences in habitat and host preferences. Gyrodactylids from Indian water bodies shows inadequate reported by Dubey et al., (1990) and Singh and Agrawal (1994). However, if body length, width etc. are considered, $G$. raipurensis shows close resemblance with the newly described one. Moreover, the measurements of key specific characters such as the haptoral armaments, the deep bar, superficial bar, marginal hooks etc. are quite distinct in the present species in comparison to the others. Comparison between the measurement of different body parts of G. gussevi and G. elegans indicus with our described one show vast differences. Both this two species are smaller in size than the newly described one. The newly described species when compared with $G$. neonephrotus almbergi shows a marked difference in 'hardparts'. All 
parts are larger'in dimension. Even, Singh and Agrawal (1994) draw and described this species by mentioning 14 hooklets in the haptor (!) which is typical generic character in Dactylogyrids (Cone, 1995). Considering its viviparous nature its position in the Gyrodactylidae family might be right but the generic characters requires attention to compare with other described ones. Considering the comparison of measurements in 'hard parts' and other morphological criteria (there are two unique characters, a deep groove runs along the length in the main part of anchors and marginal hooks without sickle filament loop or lamella.

In the present investigation the prevalence of monogenean parasites in Channa punctatus were recorded during the study period from August 2015 to July 2016. It is observed that several attempts made during the months followed from Aug-2015 to July2016 (Table: 1, Fig:2, 3, 4, 5, 6). As per Margolis it was observed that the prevalence is $44.44 \%$, mean intensity is $3.0 \%$, relative density is highest with $1.33 \%$ and index of infection is $10.67 \%$ during the month of August 2015. Followed by the prevalence is $40.91 \%$, mean intensity is $2.44 \%$, relative density is $1.0 \%$ and index of infection is 9.00\% during the month of September 2015. The prevalence is lowest with $35.00 \%$, mean intensity is $2.29 \%$, relative density is $0.80 \%$ and index of infection is $7.50 \%$ during the month of October 2015. The prevalence is $37.50 \%$, mean intensity is $2.22 \%$, relative density is $0.83 \%$ and index of infection is $7.50 \%$ during the month of November 2015. The prevalence is $38.81 \%$, mean intensity is $1.57 \%$, relative density is $0.61 \%$ and index of infection is $4.28 \%$ during the month of December 2015. The prevalence is $35.71 \%$, mean intensity is lowest with $1.40 \%$, relative density is lowest with $0.83 \%$ and index of infection is also lowest with $2.50 \%$ during the month of January 2016. The prevalence is $50.00 \%$, mean intensity is highest by $2.56 \%$, relative density is $1.28 \%$ and index of infection is $11.50 \%$ during the month of February2016. The prevalence is $56.00 \%$, mean intensity is $1.93 \%$, relative density is $1.08 \%$ and index of infection is highest with $15.12 \%$ during the month of March 2016. The prevalence is $52.17 \%$, mean intensity is $1.50 \%$, relative density is $0.78 \%$ and index of infection is $9.39 \%$ during the month of April 2016. The prevalence is $38.89 \%$, mean intensity is $1.71 \%$, relative density is $0.67 \%$ and index of infection is $4.67 \%$ during the month of May 2016. The prevalence is $45.46 \%$, mean intensity is $1.50 \%$, relative density is $0.68 \%$ and index of infection is $6.82 \%$ during the month of June 2016. The prevalence is highest with $60.00 \%$, mean intensity is $1.50 \%$, relative density is $0.90 \%$ and index of infection is $10.80 \%$ during the month of July 2016. The total 242 numbers of fish specimens examined, of these109 were infested and 213 gill parasites were recovered from the host species.

In the similar study was conducted by Raghu Ramudu Kurva and Gadadhar Dash (2013) they find out the prevalence or PFI and severity of monogenean parasites on Indian Major Carps in West Bengal fish farms. An investigation was made on Catla catla, Labeo rohita and Cirrhinus mrigala, from different parts of West Bengal. Prevalence of Dactylogyrus sp. were high during August (PFI, 83.45\%) compared to June where PFI was only $4.5 \%$. Similarly Gyrodactylus sp. showed high prevalence in August (PFI, 28.88\%) compared to its zero prevalence in June. Ahmet Özer*, Türkay Özturk (2004) studied on Gyrodactylus arcuatus Bychowsky, 1933 was identified on the three-spined stickleback, Gasterosteus aculeatus L,. Dávidová et al (2005) studied the seasonal dynamics of Gyrodactylus rhodei, a monogenean 
ectoparasite of bitter ling (Rhodeus sericeus), was studied from June 2000 to May 2001 in the Kyjovka River, Czech Republic. A negative relationship between prevalence and intensity of infection of $G$. rhodei and water temperature was found. Metrical variability of the hard parts of the parasite haptor was studied throughout the sampling season.

In the present investigation represented the seasonal variations and efficacy of the Gyrodactylus sp. parasites in Channa punctatus in the Lower manair Dam (Table; 2, Fig: 7). In the pre monsoon season 41 infected out of 83 host specimens and recover 63 Gyrodactylus sp. parasitic specimens. The prevalence is $49.40 \%$, mean intensity is 1.54 and relative density is 0.76 .
In the monsoon season 33 infected out of 84 host specimens and recover 82 Gyrodactylus $s p$. parasitic specimens. The prevalence is $39.29 \%$, mean intensity is $2.49 \%$ and relative density is $0.98 \%$. In the post monsoon season 35 infected out of 75 host specimens and recover 68 Gyrodactylus $s p$. parasitic specimens. The prevalence is $46.67 \%$, mean intensity is $1.94 \%$ and relative density is $0.91 \%$. During this period the prevalence is highest with $49.40 \%$ in pre monsoon period and lowest with $39.29 \%$ in monsoon period. The mean intensity is highest with $2.49 \%$ in monsoon period and lowest with $1.54 \%$ in pre monsoon period. The relative density is highest with $0.98 \%$ in monsoon period and lowest with $0.76 \%$ in the pre monsoon period.

Table.1 Prevalence of Gyrodactylus sp. parasites observed monthly in Channa punctatus gills during the different months in Lower Manair Dam

\begin{tabular}{|c|c|c|c|c|c|c|c|}
\hline $\begin{array}{c}\text { Month } \\
\text { 2015-16 }\end{array}$ & $\begin{array}{c}\text { Total no. } \\
\text { of hosts } \\
\text { examine } \\
\text { d }\end{array}$ & $\begin{array}{c}\text { Total no. } \\
\text { of } \\
\text { infected } \\
\text { hosts } \\
\text { examined }\end{array}$ & $\begin{array}{c}\text { Total } \\
\text { no. of } \\
\text { parasite } \\
\text { s }\end{array}$ & $\begin{array}{c}\text { prevalenc } \\
\text { e }\end{array}$ & $\begin{array}{c}\text { Mean } \\
\text { intensity }\end{array}$ & $\begin{array}{c}\text { Relative } \\
\text { Density }\end{array}$ & $\begin{array}{c}\text { Index of } \\
\text { Infection }\end{array}$ \\
\hline Aug-15 & $\mathbf{1 8}$ & $\mathbf{0 8}$ & 24 & 44.44 & $\mathbf{0 3 . 0 0}$ & 01.33 & 10.67 \\
\hline Sep-15 & 22 & 09 & 22 & 40.91 & 02.44 & 01.00 & 09.00 \\
\hline Oct-15 & 20 & 07 & 16 & 35.00 & 02.29 & 00.80 & 05.60 \\
\hline Nov-15 & 24 & 09 & 20 & 37.50 & 02.22 & 00.83 & 07.50 \\
\hline Dec-15 & 18 & 07 & 11 & 38.81 & 01.57 & 00.61 & 04.28 \\
\hline Jan-16 & 14 & 05 & 07 & 35.71 & 01.40 & 00.50 & 02.50 \\
\hline Feb-16 & 18 & 09 & 23 & 50.00 & 02.56 & 01.28 & 11.50 \\
\hline Mar-16 & 25 & 14 & 27 & 56.00 & 01.93 & 01.08 & 15.12 \\
\hline Apr-16 & 23 & 12 & 18 & 52.17 & 01.50 & 00.78 & 09.39 \\
\hline May-16 & 18 & 07 & 12 & 38.89 & 01.71 & 00.67 & 04.67 \\
\hline Jun-16 & 22 & 10 & 15 & 45.46 & 01.50 & 00.68 & 06.82 \\
\hline Jul-16 & 20 & 12 & 18 & 60.00 & 01.50 & 00.90 & 10.80 \\
\hline Total & 242 & 109 & 213 & - & - & - & - \\
\hline
\end{tabular}


Table.2 Seasonal variations and efficacy of the Gyrodactylus sp. parasites in Channa punctatus

\begin{tabular}{|c|c|c|c|c|c|c|}
\hline Seasons & $\begin{array}{c}\text { Total No. } \\
\text { of Hosts } \\
\text { Examined }\end{array}$ & $\begin{array}{c}\text { Total No. of } \\
\text { Infected } \\
\text { Hosts } \\
\text { Examined }\end{array}$ & $\begin{array}{c}\text { Total No. } \\
\text { of parasites }\end{array}$ & Prevalence & $\begin{array}{c}\text { Mean } \\
\text { Intensity }\end{array}$ & $\begin{array}{c}\text { Relative } \\
\text { Density }\end{array}$ \\
\hline Pre & 83 & 41 & 63 & 49.40 & 01.54 & 0.76 \\
\hline Monsoon & 84 & 33 & 82 & 39.29 & 02.49 & 0.98 \\
\hline Post & 75 & 35 & 68 & 46.67 & 01.94 & 0.91 \\
\hline
\end{tabular}

Fig.1 A photograph of Gyrodactylus sp. Dorsal, anterior and posterior views
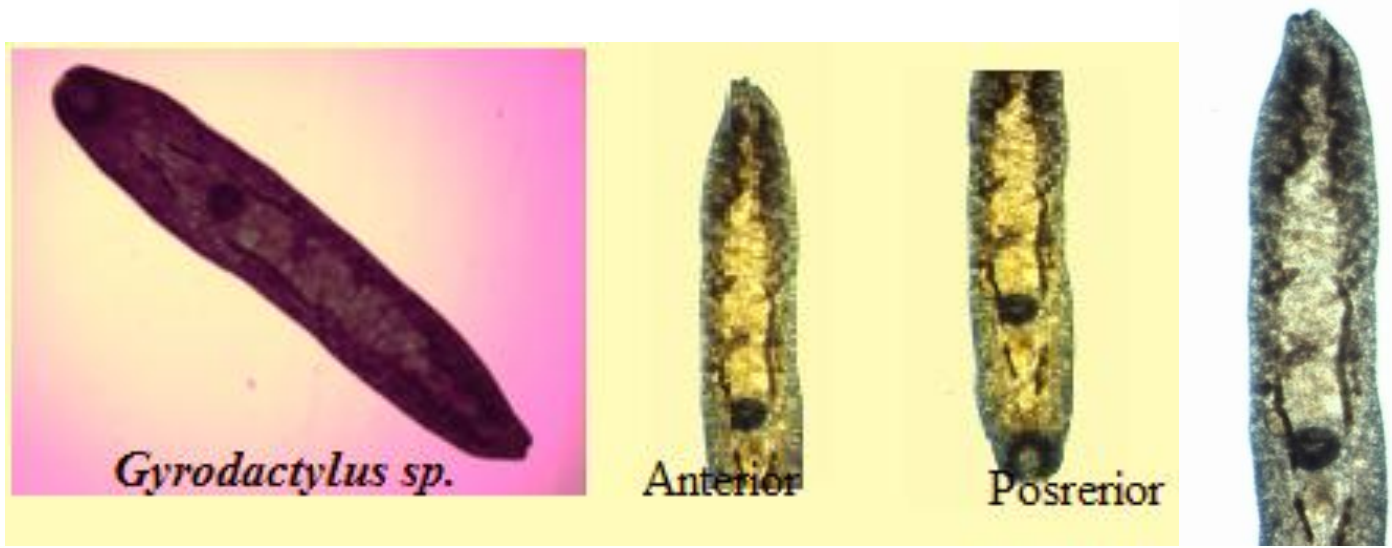

Fig.2 Prevalence of Gyrodactylus sp. parasites observed monthly in Channa punctatus.

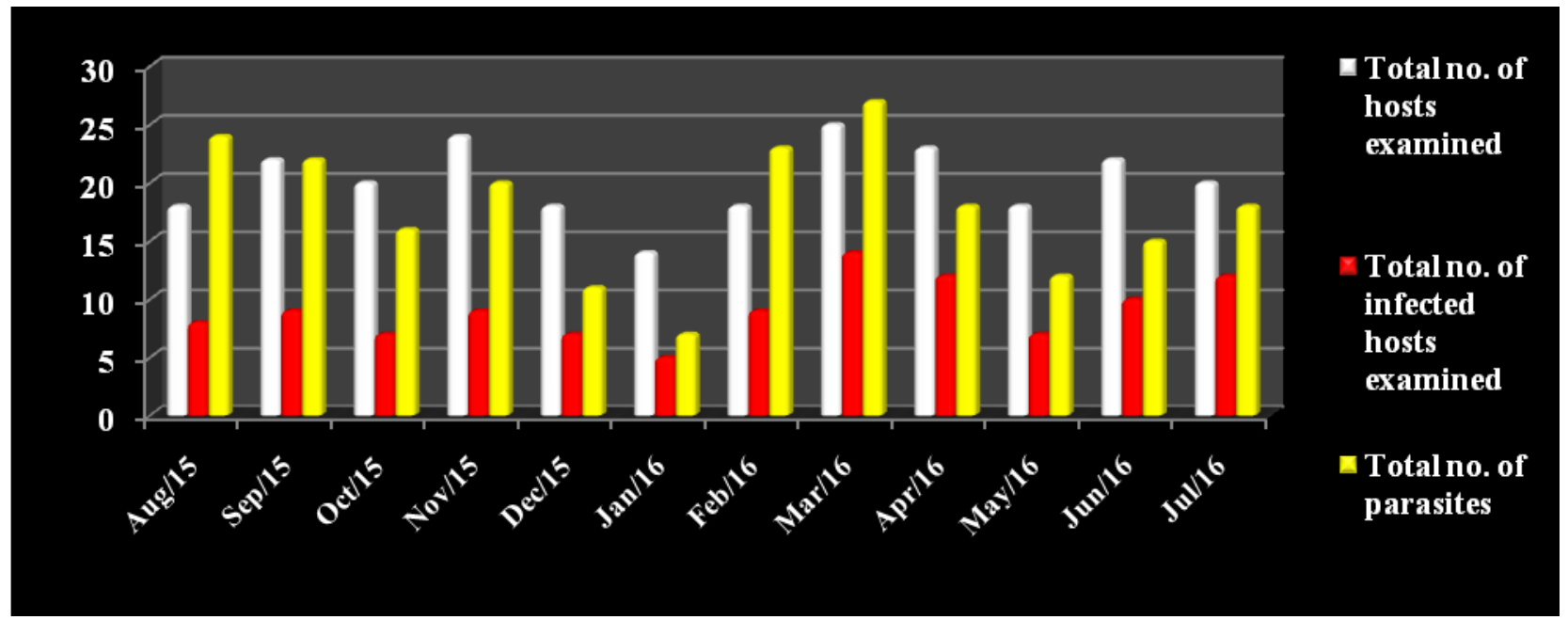



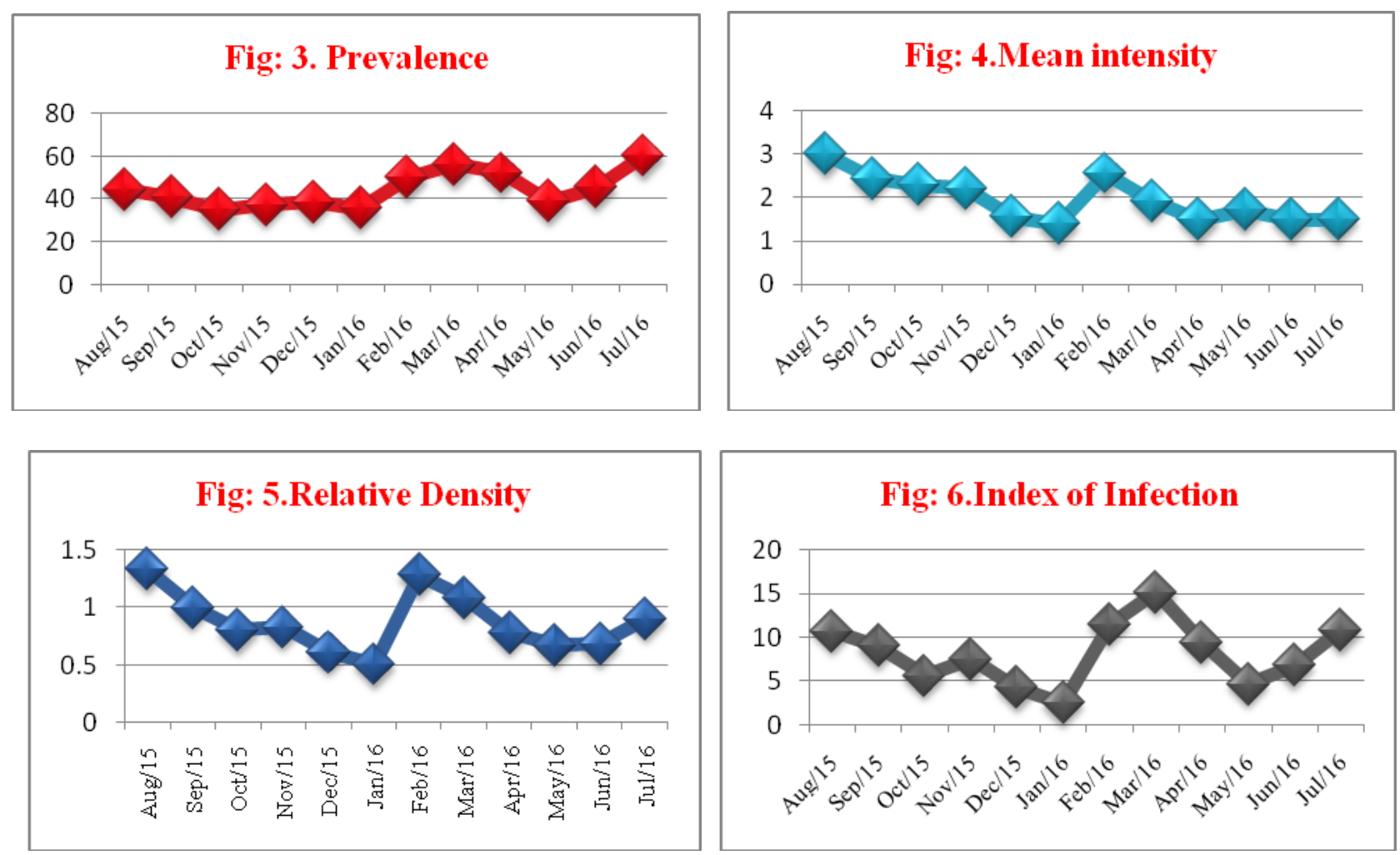

Fig.7 Seasonal variations and efficacy of Gyrodactylus sp. parasites in the Channa punctatus

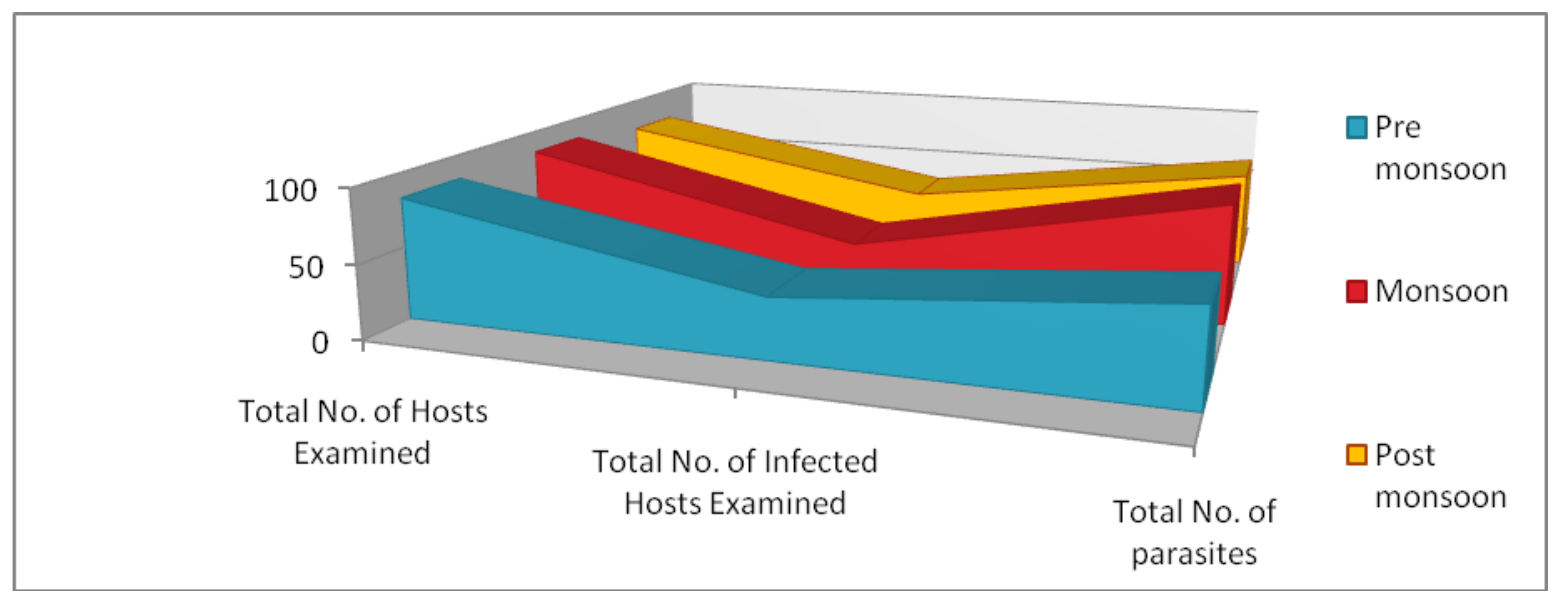

The frequency index were further classified into rare $(0.1-9.9 \%)$, occasional (10$29.9 \%)$, common $(30-69.9 \%)$ and abundant (70-100\%) indicated by Srivastava C.B. (1980). According to Margolis the Parasitic Frequency Index (PFI) is 02.50 to $15.12 \%$ in Channa punctatus at Lower Manair Dam. It represents that occasional in
August 2015, February 2016 and July 2016, rest of the study period is rare (Table: 1). Seasonal variation of the relative density was represented as rear in pre monsoon, monsoon and post monsoon periods (Table: 2, Fig: 7). Blazek et al., (2008), Chubb (1977), Kirby (1981), and Mo (1992) investigated the seasonal variation in 
parasite occurrence and microhabitat distribution of monogenean parasites of Gobid fishes. Koskivaara et al., (1991) observed that the seasonal occurrence of gyrodactylid monogeneans on the Rutilus rutilus and variations between four lakes of differing water quality.

A species of Monogenean trematode under the genus Gyrodactylus from the teleostean host Channa punctatus (Bloch) is described and illustrated. The other known species from India along with the present one has been critically reviewed and compared in a comparative chart. The species has been described for the first time from Lowe Manair Dam, Karimnagar, India. The Parasitic Frequency Index (PFI) is $02.50 \%$ to $15.12 \%$ in Channa punctatus at Lower Manair Dam. It represents that occasional in August 2015, February 2016 and July 2016, rest of the study period is rare. In the seasonal wise the relative density is represented as rear in pre monsoon, monsoon and post monsoon periods.

\section{Acknowledgements}

The author would like to thank University Grant Commission for rendering financial assistance and Commissioner Collegiate Education Telangana, Govt. Degree College, Jammikunta, for providing necessary facilities. Thanks are also my colleague Dr. K. Rama Rao, Asst. Professor for his help with illustrations.

\section{References}

Ahmet Özer, Türkay Öztürk. 2004. Prevalence and Intensity of Gyrodactylus arcuatus Bychowsky, 1933 (Monogenea) Infestations on the Three-Spined Stickle back, Gasterosteus aculeatus L., 1758

Aniruddha Jha, Rupendu Ray and Sumit
Homechaudhuri. 2002. Gyrodactylus presidencyus sp. nov. (trematoda: monogenea) from a fresh water teleost, Channa punctatus (bloch) in West bengal, India Post Graduate Department of Zoology, Presidency College, Kolkata-700 073, India. Rec. Zool. Surv. India: 100 (Part 1-2): 45 54, 2002

Bakke, T.A., Harris, P.D., Cable, J. 2002. Host specificity dynamics: observations on gyrodactylid monogeneans. Int. J. Parasitol., 32: 281-308.

Beverly-Burton, M. 1984. Monogenea and Turbullaria. In : Margolis, L. and Kabata, Z. (eds) Guide to Parasites of Fishes of Canada Part I. Canadian Special Publication of Fisheries and Aquatic Sciences, No. 74.

Blazek, B., Jarkowsky, J., Koubkova, B., Gelnar, M. 2008. Seasonal variation in parasite occurrence and microhabitat distribution of monogenean parasites of gudgeon Gobio gobio (L.). Helminthologia, 45: 185-191.

Brooks, D.R. and E.P. Hoberg. 2000.Triage for the biosphere: the need and rationale for taxonomic inventories and phylogenetic studies of parasites, Comparative Parasitol., 67: 1-25.

Bychowsky, B.E. 1957. Monogenetic trematodes, their systematic and phylogeny (English translation), Washington: American Institute of Biological Science. pp. 509.

Bychowsky, B.E. 1957. Monogeneticheskiye sosal' shchiki ikh sistelna; filogeniya (Monogenetic flukes, their systematics and phylogeny). Mosco-Leningrad Acad. Sci., USSR press, pp. 1-509.

Bychowsky, B.E. 1962. Monogentic Trematodes: Their Systametic and Phylogeny, p. 242. Graphic Arts Press. Chubb, J.C. 1977. Seasonal occurrence of 
helminths in freshwater fishes. Part I. Monogenea. Adv. Parasitol., 15: 133199.

Chubb, J.C. 1977. Seasonal occurrence of helminths in freshwater fishes. Part 1. Monogenea. Adv. Parasitol., 15: 133199

Cone, D.K. 1995. Monogenea (Phylum Platyhelminthes) In : Woo, P. T. K. (ed.) Fish Diseases and Disorders: Protozoan and Inetazoan Infections. CAB International, UK, pp. 289-327.

Cone, D.K., Beverly-Burton, M., Wiles, M. and MacDonald, T.E. 1983. The taxonomy of Gyrodactylus (Monogenea) parasitizing certain salmonid fishes of North America, with a description of Gyrodactylus nerkae n. sp. Can. J. Zool., 61: 25832597.

Dávidová, $\quad$ M. J., $\quad$ Jarkovský, I., Matějusová, M., Gelnar. 2005. Seasonal occurrence and metrical variability of Gyrodactylus rhodei Žitňan $1964 \quad$ (Monogenea, Gyrodactylidae) Parasitol. Res., Volume 95, Issue 6, pp 398405.

Dubey, A., Gupta, A.K. and Agarwal, S.M. 1990. Studies on monogenean parasites in fresh water fishes at Raipur. III. Three new species of the Genus Gyrodaetylus Nordmann (1832). Ind. J. Helnlintlzol., 42: 1-8.

Gussev, A.V. 1978. Monogenoidea of fresh water fishes. Principles of Systematics, analysis of world fauna and its evolution. Parasitol. Se., 28: 96-198.

Gussev, A.V. 1985. Multicellular parasites (part one). In : Bauer, O. N. (ed.) Handbookfor identifying Parasites of Fish Fauna of the USSR. 'Hayka', Leningrad.

Harris, P.D. 1986. Species of Gyrodactylus VOIl Nordmann, 1832 (Monogenea :
Gyrodactylidae) from Poecilia reticulata Peters. J. Nat.

Hoffman, G.L. 1979. Helminth parasite. In : Plumb, 1. A. (ed.) Principal Diseases of Farm-raised Catfish. Southern Cooperative Series No. 225, pp. 40-58.

Hossain, M.D., M.K. Hossain, M.H. Rahaman, A. Akter and D.A. Khanom. 2008. Prevalence of ectoparasites of carp fingerlings at Santaher, Bogra. Univ. J. Zool., 27: 17-19.

Ivona, M. 2004. Monogenean parasites in Adriatic cage-reared fish. Acta Adriatica. 5:65-73. [13] B.E. Bychowsky. (1957). Monogenetic trematodes, their systematic and phylogeny (English translation), Washington: American Institute of Biological Science, pp. 509.

JHA, et al. 1981. Gyrodactyills presidel1cyus sp. nov. (Trematoda: Monogenea) in West Bengal.

Kirby, J.M. 1981. Seasonal occurrence of the ectoparasite Gyrodactylus atratuli on spotfin shiners. Trans. Am. Fish. Soc., 110: 462-464.

Koskivaara, M., Valtonen, E.T., Prost, M. 1991. Seasonal occurrence of gyrodactylid monogeneans on the roach (Rutilus rutilus);and variations between four lakes of differing water quality in Finland. Aqua Fenn, 21: 4755.

Malmberg, G. 1970. The excretory systems and the marginal hooks as a basis for the systematics of Gyrodactylus (Trematoda, Monogenea). Ark. Zool., 23: 1-235.

Mo, T.A. 1992. Seasonal variations in the prevalence and infestation intensity of Gyrodactylus salaris Malmberg, 1957 (Monogenea: Gyrodactylidae) on Atlantic salmon parr, Salmo salar L. in the River Batnfjordselva. J. Fish Biol., 42: 697-707.

Poulin, R. and S. Morand. 2000. The 
diversity of parasites, Quarterly Review of Biol., 75: 277-93.

Poulin, R. and S. Morand. 2000. The diversity of parasites, Quarterly Review of Biol., 75: 277-93.

Raghu Ramudu Kurva and Gadadhar Dash. 2013. Prevalence of Monogenean Parasites on Indian Major Carps in Bheries of West Bengal. IJCBS, 4: 1321.

Singh, H.S. and Agrawal, S. 1994. Description and excretory system of Gyrodactylus neonephrotus malmbergi n. sp. Uttar Pradesh. J. Zool., 14: 4551.

Soylu, E., B. Rüzgar and M. Soylu. 2010. Seasonal dynamics and spatial distribution of Dactylogyrus on the gills of roach (Rutilus rutilus L.) from Lake Sapanca, Turkey. Turkey J. Zool., 34: 393- 398.

Srivastava, C.B. 1980. Estimation of helminthic infections. Proceedings Workshop Technology Parasitol. Zool. Survey of India, pp. 29-31.

Tripathi, Y.R. 1957. Monogenetic trematodes from fishes of India. Ind. $J$. Helminthol., 9: 1-149.

Venkatanarsaiah, J. and Kulkarni, T. 1980. Gyrodactylus eutheraponsis n. sp. from the gills of a perciform fish, Eutherapon therops. Proc. Indian Acad. Parasitol., 1: 12-15.

\section{How to cite this article:}

Leela Bommakanti. 2016. Prevalence of Gyrodactylus sp. in Channa punctatus (Bloch, 1793) Monogenean Ecto-parasite Family: Gyrodactylidae at Lower Manair Dam. Int.J.Curr.Microbiol.App.Sci. 5(9): 496-507. doi: http://dx.doi.org/10.20546/ijcmas.2016.509.055 